\title{
Studi Fisis untuk Menentukan Karakteristik Air Tanah di Desa Bercak, Kecamatan Berbah, Kabupaten Sleman, Daerah Istimewa Yogyakarta
}

Ika Rahayuningtyas* dan Wagini R

\begin{abstract}
Abstrak
Telah dilakukan penelitian untuk menentukan karakteristik air tanah di sekitar peternakan sapi di desa Bercak, Kecamatan Berbah, Kabupaten Sleman, Daerah Istimewa Yogyakarta. Sampel uji berupa air tanah yang sehari-hari digunakan oleh masyarakat sekitar sebagai sumber air bersih. Karakteristik air ditentukan melalui parameter fisika, kimia, dan biologi. Sampel uji diambil berdasarkan titik pengambilan sampel sejauh 20 meter, 30 meter, dan 40 meter, serta bertujuan untuk mengetahui pengaruh adanya peternakan sapi terhadap karakteristik sampel. Dari hasil uji semua sampel masih berada dibawah standar baku yang diperbolehkan untuk parameter tegangan permukaan, viskositas, daya hantar listrik, kekeruhan, padatan terlarut, $\mathrm{pH}$, kesadahan, kandungan nitrit, dan kandungan detergen. Sedangkan untuk parameter uji indeks bias semua sampel mengalami penyimpangan, dengan nilai penyimpangan paling besar adalah sampel 3 pada jarak 20 meter, yaitu sebesar $(1,3400 \pm 0,0013)$. Kandungan nitrat semua sampel melebihi nilai standar maksimum yang diperbolehkan, dengan penyimpangan paling besar adalah sampel 1 pada jarak 30 meter dari pusat polutan, yaitu sebesar 20,58 $\mathrm{mg} / \mathrm{l}$. Total coliform untuk semua sampel melebihi standar maksimum yang diperbolehkan, yaitu bernilai $>1600$ dan 240 dalam $100 \mathrm{ml}$, dari karakteristik yang diketahui, dapat dikatakan air tanah telah tercemar karena tidak memenuhi syarat air kualitas air bersih menurut Keputusan Menteri Kesehatan RI No. 416/Menkes/Per/IX/1990 tentang syarat-syarat dan Pengawasan Kualitas Air.
\end{abstract}

kata kunci: limbah peternakan sapi; pencemaran air tanah; karakteristik; kualitas; air

\begin{abstract}
The research had been done about characteristic study for ground water in the cattle farm of Bercak village. Ground water tested was using by villager as clean water resources for daily life. The charactheristics of ground water was determined by the parameters of physics, chemistry, and biology. Samples taken by the sampling point as far as 20 meters, 30 meters and 40 meters, and aims to determine the impact of cattle farm on samples characteristics. From the test results of all samples was below the standard that allowed for parameter surface tension, viscosity, electrical conductivity, turbidity, dissolved solids, $\mathrm{pH}, \mathrm{CaCO}_{3}$, nitrite, and detergents. Whereas for parameters refractive index all of sample exceed the standards allowed, with greatest deviations is sample 3 at 20 meters, which is equal to $(1.3400 \pm 0.0013)$. Nitrate content all of sample exceed the standards allowed, with the most deviation is sample 1 at 30 meters from the cattle farm, which amounted to $20.58 \mathrm{mg} / \mathrm{I}$. Total coliform all of sample exceed the standart allowed, which is equal to $>1600$ and 240 in $100 \mathrm{ml}$ of sample, of known characteristics, can be said groundwater had been contaminated due to ineligible water quality of clean water according to Minister of Health Decree No.416/Menkes/Per/IX / 1990 concerning the Terms and Water Quality Monitoring.
\end{abstract}

keywords: cattle farm; ground water pollution; characteristic; quality; water

${ }^{*}$ Korespondensi: ika.rahayuningtyas@mail.ugm.ac.id

Departemen Fisika, Universitas Gadjah Mada, Sekip Utara PO BOX BLS

21, 55281 Yogyakarta, Indonesia
Informasi lengkap tentang penulis dapat dilihat pada akhir artikel

${ }^{\dagger}$ Equal contributor 


\section{Pendahuluan}

Kebutuhan air merupakan salah satu kebutuhan pokok manusia. Kebutuhan pokok yang lain adalah pangan. Pertumbuhan penduduk yang semakin meningkat maka meningkat pula kebutuhan akan pangan. Selain karbohidrat yang didapat dari hasil - hasil pertanian, untuk pertumbuhan manusia juga membutuhkan protein hewani yang didapat dari sektor peternakan. Maka peternakan sapi mulai berkembang dan tumbuh dari waktu kewaktu. Salah satu usaha peternakan yang limbahnya sangat besar adalah peternakan sapi.Limbah peternakan sapi sebagai faktor negatif dari usaha peternakan adalah fenomena yang tidak dapat dihilangkan dengan mudah. Selain memperoleh keuntungan dalam hal bisnis, usaha peternakan sapi juga menimbulkan dampak negatif bagi lingkungan dan kesehatan masyarakat. Limbah yang langsung dibuang ke lingkungan tanpa diolah akan mencemari udara, air dan tanah. Limbah peternakan ini dapat dibagi menjadi limbah gas, padat, dan cair. Beberapa gas yang dihasilkan dari limbah ternak antara lain amonium, hidrogen sulfida, karbondioksida $\left(\mathrm{CO}_{2}\right)$ dan metana $\left(\mathrm{CH}_{4}\right)$. Gas - gas tersebut selain merupakan gas efek rumah kaca (Green House Gas) juga menimbulkan bau tak sedap dan mengganggu kesehatan manusia. Feses termasuk limbah padat peternakan. Salah satu contoh limbah cair adalah urine sapi yang berasal dari metabolisme nitrogen dalam tubuh (urea, asam urat, dan keratin) serta $90 \%$ urin terdiri dari air sehingga jenis limbah ini lebih mudah meresap dan mempengaruhi lingkungan di sekitarnya. Pada tanah, limbah cair peternakan sapi dapat melemahkan daya dukung tanah sehingga menyebabkan polusi tanah. Sedangkan pada air, mikroorganisme patogenik (penyebab penyakit) yang berasal dari limbah cair ternak akan mencemari lingkungan perairan [1]

Limbah peternakan sapi memberi dampak negatif terhadap kualitas air tanah, maka perlu dilakukan pengujian atau penelitian. Penelitian yang terkait dengan kualitas air tanah di sekitar peternakan sapi ini akan dilaksanakan di desa Bercak, Kecamatan Berbah, Kabupaten Sleman, Yogyakarta. Pemilihan pengambilan sampel air tanah di desa Bercak, Kecamatan Berbah, Kabupaten Sleman, Yogyakarta dikarenakan adanya peternakan sapi yang telah lama berdiri di wilayah ini. Peternakan sapi ini berada dekat dengan pemukiman warga, serta pembuangan limbah peternakan sapi tidak tersedia instalasi. Sedangkan penelitian tentang kualitas air tanah terutama air sumur di sekitar peternakan sapi ini juga belum pernah dilakukan, apakah masih layak dipergunakan atau dimanfaatkan secara bebas untuk keberlangsungan makhluk hidup karena sangat rentan terhadap pencemaran serta pernah adanya keluhan dari warga sekitar pada saat digunakan. Atas dasar itu maka diperlukan pengujian dan penelitian terhadap karakteristik besaran-besaran fisis, besaran-besaran kimia, serta pengujian terhadap parameter biologi. Karakteristik fisis, kimia,dan biologi air sumur tersebut kemudian digunakan untuk menentukan tingkat kandungan polutan air sumur yang ada di sekitar tempat peternakan tersebut.

\section{Dasar Teori}

\subsection{Pencemaran Air}

Pencemaran air adalah masuknya atau telah dimsukkannya makhluk hidup, zat, energi, dan atau komponen lain ke dalam air baik karena kegiatan manusia maupun terjadi secara alamiah sehingga menyebabkan kualitas air turun hingga pada skala tertentu dan air tidak dapat berfungsi sesuai dengan kegunaannya [2]

\subsection{Limbah Peternakan}

Limbah ternak merupakan sisa buangan dari usaha pemeliharaan ternak, rumah pemotongan ternak, serta pengolahan produk ternak. Masalah lingkungan yang ditimbulkan oleh peningkatan industri peternakan sapi adalah limbah yang langsung dibuang ke lingkungan tanpa adanya pengolahan terlebih dahulu. Limbah peternakan sapi merupakan salah satu sumber utama dalam sektor peternakan sapi. Limbah peternakan umumnya meliputi semua kotoran yang dihasilkan dari suatu kegiatan usaha peternakan, baik berupa limbah padat, cairan, ataupun sisa pakan [3]

Kotoran sapi adalah limbah perternakan yang merupakan buangan dari usaha perternakan sapi yang bersifat padat dan dalam pembuangannya sering bercampur dengan urine dan gas seperti metana dan amoniak [4]. Kandungan unsure hara dalam dalam kotoran sapi antara lain nitrogen $0,29 \%, \mathrm{P}_{2} \mathrm{O}_{5}$ 0,17\% dan $\mathrm{K}_{2} \mathrm{O} \quad 0,35 \%$ [5]. Unsur makro dari kotoran sapi adalah $\mathrm{N} 2,04 \%, \mathrm{P}$ 0,76\%, K 0,82\%, Ca 1,29\%, Mg $0,48 \%$ sedangkan untuk unsur mikronya adalah $\mathrm{Mn}$ $528 \%$, Fe 2597\%, Cu 56\%, dan Zn 239\%. Sedangkan untuk limbah cair yang berupa urine sapi, memiliki kandungan sebagai berikut : Nitrogen (N) : 1,4 hingga $2,2 \%$, fosfor $(\mathrm{P})$ : 0,6 hingga $0,7 \%$, dan kalium $(\mathrm{K})$ 1,6 hingga $2,1 \%[6]$.

\subsection{Parameter Kualitas Air}

Parameter kualitas air yang disampling secara periodik dan dicatat datanya meliputi $\mathrm{pH}$, oksigen terlarut (DO), BOD, temperatur, daya hantar 


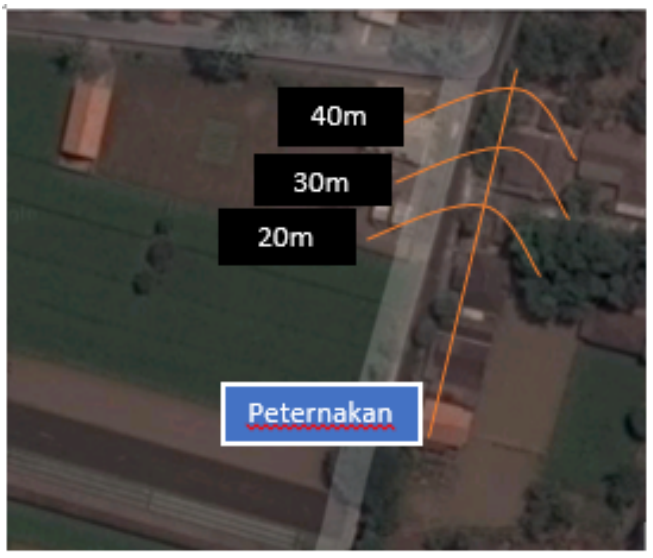

Gambar 1 Skema Tahapan Penelitian

listrik atau konduktivitas, kekeruhan (turbidity), TOC, COD, toxicity, Nitrogen, Fosfor, logam berat, Sulfat, busa, bau $\left(\mathrm{H}_{2} \mathrm{~S}\right)$, dan radioaktif. Senyawa bakteriologis seperti Fecal Coliform juga perlu dicatat,dan kemudian dilakukan pengujian oleh laboratorium yang tersertifikasi. Secara umum parameter kualitas air dibagi dalam 4 (empat) bagian yaitu: parameter fisik, kimia, biologi dan radioaktif. [7].

\section{Metode Penelitian}

\subsection{Tahapan Penelitian}

Dalam pelaksanaannya penelitian ini dibagi dalam beberapa tahap agar lebih memudahkan dan berjalan dengan baik sehingga tujuan penelitian ini dapat tercapai. Tahapan ini dibagi menjadi 3 tahapan pokok, yaitu: tahap persiapan, tahap pelaksanaan dan tahap penulisan laoran penelitian, seperti yang telah tersaji dalam Gambar 1.

\subsection{Tempat dan Waktu Penelitian}

Penelitian dilakukan sejak tanggal 3 November 2015-20 Februari 2016. Tempat penelitian dibagi menjadi dua, yaitu tempat pengambilan sampel dan tempat pengujian sampel. Tempat pengambilan sampel adalah di desa Bercak, Kecamatan Berbah, Kabupaten Sleman, Yogyakarta. Pengambilan sampel dilakukan pada tanggal 03 November-15 November 2015. Pengujian sampel dilakukan di Laboratorium BTKL Yogyakarta dan Laboratorium Fisika Dasar FMIPA UGM. Pengujian beberapa parameter fisika, kimia, dan biologi dilakukan di Laboratorium BTKL Yogyakarta dan pengujian parameter fisika lainnya dilakukan di Laboratorium Fisika Dasar FMIPA UGM.

Gambar 1 Lokasi Pengambilan Sampel

\subsection{Alat dan Bahan}

Bahan yang digunakan dalam penelitian ini adalah sampel air tanah di sekitar peternakan sapi desa Bercak, Kecamatan Berbah, Kabupaten Sleman, Yogyakarta. Sampel diambil dari 6 titik yaitu 1, 2, $3,4,5$, dan 6 . Titik 3,4 , dan 5 berjarak \pm 20 meter dari peternakan sapi, titik 1 dan 6 berjarak \pm 30 meter dari peternakan sapi, dan titik 2 berjarak \pm 40 meter dari peternakan sapi. Alat-alat yang digunakan dalam penelitian ini dikelompokkan menjadi:

1 Alat pengambilan sampel: botol air mineral dengan ukuran 1,5 L dan $600 \mathrm{~mL}$ serta botol steril bervolume $500 \mathrm{ml}$. Botol steril ini dipinjam dari Laboratorium BTKL Yogyakarta. Sebelum digunakan untuk mengambil air, botol-botol ini dibersihkan terlebih dahulu.

2 Alat pengujian di laboratorium:

(a) Lab. Fisika Dasar : refraktometer ABBE, bejana U, untai jembatan Wheatstone, indikator (headphone), tahanan Buzzer, mistar, jangka sorong, pipa kapiler, gelas ukur, statif dengan penjepit, mikroskop geser, dan thermometer.

(b) BTKL Yogyakarta : hydrometer, $\mathrm{pH}$ meter, TDS meter, turbidimeter dan Atomic Absorption Spectrofotometer (AAS).

\subsection{Pengujian Kualitas Air}

\subsubsection{Pengukuran daya hantar listrik}

Pengukuran daya hantar listrik dengan prinsip jembatan wheatstone dan hambatan buzzer ini yang pertama adalah cairan sampel yang akan diteliti dimasukkan dalam bejana berbentuk $U$ dengan volume100 $\mathrm{ml}$ hingga elektroda dalam kaki-kaki bejana tercelup. Setelah itu bejana U dipasang pada tempatnya dan untai jembatan dirangkai seperti pada Gambar 2. Setelah alat terangkai, sumber listrik dihidupkan dengan tahanan buzzer $\left(\mathrm{R}_{2}\right)$ sebesar 1.000 $\Omega$ dan potensiometer diputar hingga terdengar bunyi paling lemah pada headphone. Nilai $R_{3}$ dan $R_{4}$ dicatat. Langkah-langkah ini dilakukan sebanyak lima kali dengan variasi $R_{2}$ mulai dari 1.000-3.000 $\omega$.

Pengukuran tegangan permukaan menggunakan metode kenaikan air dalam pipa kapiler. Besarnya nilai tegangan permukaan diukur dengan langkah kerja yang pertama pipa kapiler dibersihkan dengan menggunakan cairan sampel yang akan diteliti dan dikeringkan. Setelah itu diameter lubang pipa diukur dengan mikrometer mikroskop geser sebanyak lima kali pengukuran dan diambil nilai rata-ratanya. Sampel dimasukkan ke dalam gelas ukur dengan volume $30 \mathrm{ml}$ dan pipa kapiler dimasukkan ke dalam gelas ukur dengan kedalaman $0,5 \mathrm{~cm}$. Pipa kapiler dijepit dengan statif agar tidak bergeser. 


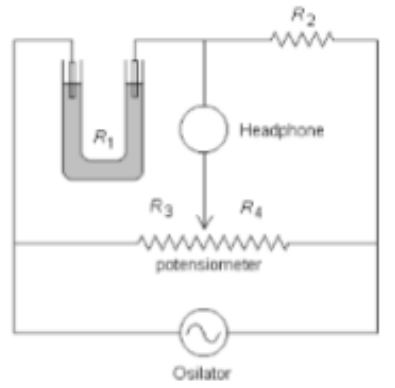

Gambar 2 Skema alat pengukuran daya hantar listrik

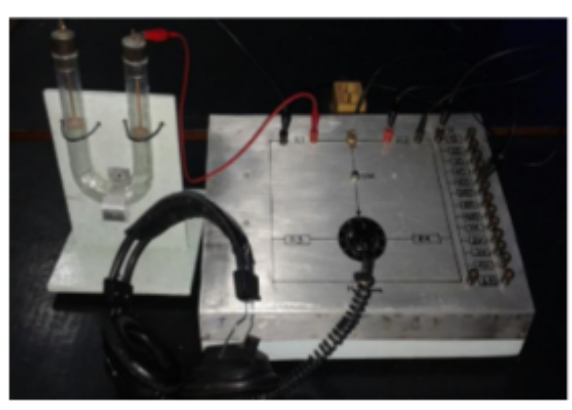

Gambar 3 Rangkaian alat jembatan wheatstone Pengukuran tegangan permukaan.

Setelah itu, tinggi permukaan cairan pada pipa kapiler diamati baik dari dalam maupun dari luar pipa kapiler. Langkah terakhir adalah skala dibaca dengan menggunakan mikroskop geser. Pada langkah penuangan sampel, pemasukkan ke gelas ukur, pengamatan pipa kapiler dan pembacaan pipa kapiler ini diulangi dengan penambahan volume sebanyak 10 $\mathrm{ml}$ yang menyebabkan kedalaman pipa kapiler yang tercelup bertambah $0,5 \mathrm{~cm}$. Langkah ini dilakukan hingga volume cairan sebanyak $50 \mathrm{ml}$. setelah selesai pipa kapiler diangkat dan dikeringkan kembali.

Pengukuran indeks bias zat cair dilakukan dengan menggunakan refraktometer ABBE dan sumber cahaya monokromatis sinar kuning.

Langkah-langkah menggunakan refraktometer, langkah pertama menyalakan lampu penerang. Setelah itu mengatur fokus lensa refraktometer. Sebelum digunakan, prisma refraktometer dibersihkan dengan tisu, diatur posisi cahaya yang masuk kemudian sampel air yang akan diuji diteteskan pada prisma. Setelah itu prisma penerang dan pengukur dirapatkan kembali. Langkah terakhir, pemutar sebelah kanan diputar sampai diperoleh batas gelap terang tepat pada garis silang. Skala yang terukur dicatat sebagai nilai indeks bias dari sampel. Pengujian sampel

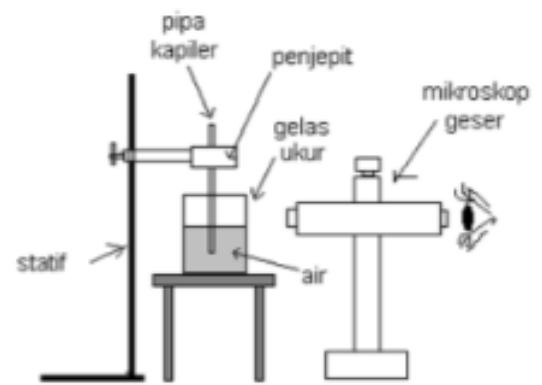

Gambar 4 Skema alat pengukuran tegangan muka.

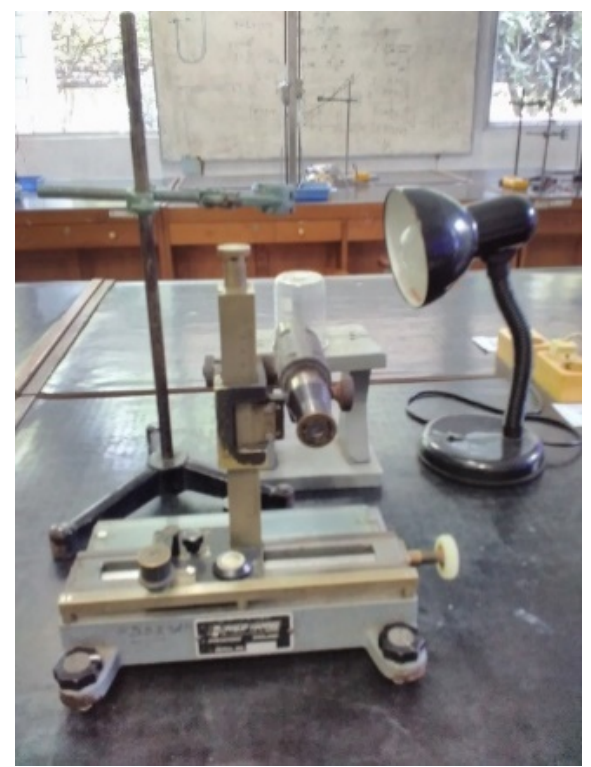

Gambar 5 Alat pengukuran tegangan muka Pengukuran indeks bias.

ini dilakukan sebanyak tiga kali dan dicari nilai rata-ratanya.

\subsubsection{Pengukuran viskositas}

Pengukuran nilai visikositas cairan ini dimulai dengan menuangkan sampel di gelas ukur sebanyak $100 \mathrm{ml}$. Setelah itu, sampel dipompa sampai melewati titik A-B. Waktu pengaliran air sampel ini dicatat. Suhu percobaan diukur dengan memasang termometer ke dalam termostat. Percobaan ini dilakukan sebanyak 5 kali dengan sampel yang sama, dengan waktu pengambilan yang berbeda.

\subsubsection{Pengukuran Parameter Lain}

Pengujian parameter untuk zat padat terlarut, kekeruhan, kesadahan, $\mathrm{pH}$, nitrat, nitrit, deterjen, dan juga total Coliform dilakukan di BTKL (Badan 


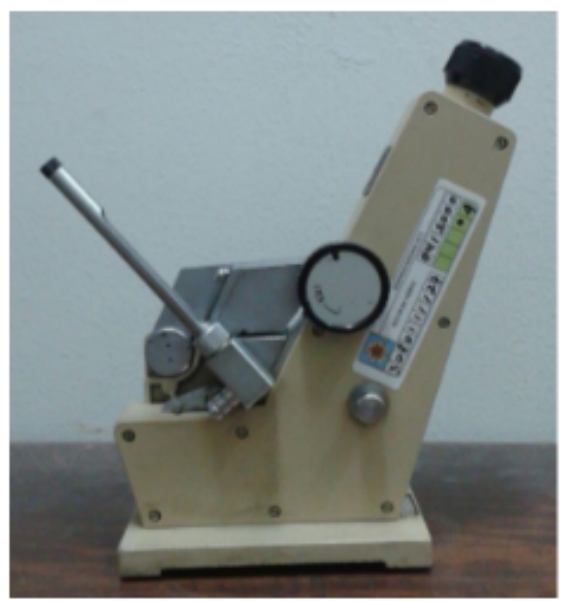

Gambar 6 Refraktometer ABBE.

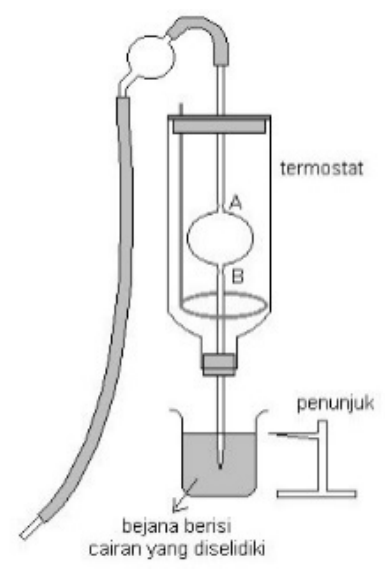

Gambar 7 Skema alat pengukuran viskositas

Teknologi Kesehatan Lingkungan) Yogyakarta. Pengujian dilaksanakan dari tanggal 03 November 2015 sampai dengan 04 Desember 2015.

\subsection{Analisa Data}

Pengujian sampel yang telah dilakukan akan ditampilkan dalam bentuk diagram batang. Kemudian dibandingkan dengan batas maksimum kadar yang diperbolehkan untuk setiap parameter yang telah diuji. Setelah dibandingkan maka akan diperoleh apakah kualitas air tersebut telah memenuhi standar kesehatan dan layak serta berkualitas untuk dikonsumsi masyarakat sebagai air bersih sesuai dengan Keputusan Menteri Kesehatan RI No. 416/Menkes/Per/IX/1990 [8] tentang syarat-syarat dan Pengawasan Kualitas Air.

Metode parangkingan juga digunakan dalam analisa data ini untuk mengetahui tingkat pencemaran

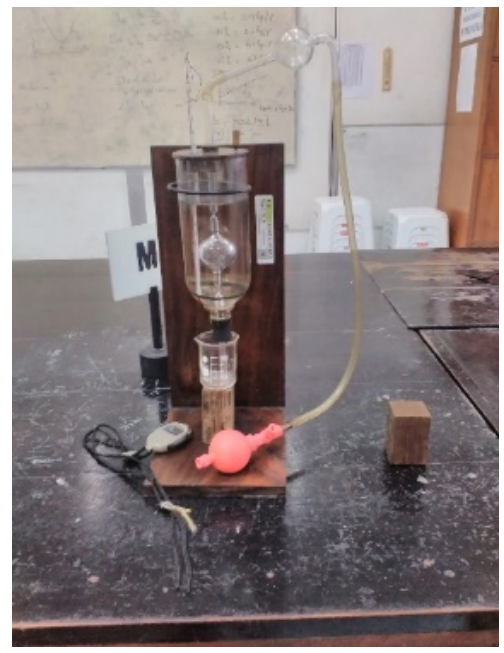

Gambar 8 Viskosimeter Ostwald

yang diwakili oleh pengambilan titik-titik sampel. Metode ini dilakukan dengan cara memberi rangking untuk setiap parameter uji. Rangking ini kemudian dijumlahkan untuk masing-masing sampel. Hasil penjumlahan ini kemudian dibagi dengan jumlah parameter uji. Semakin kecil hasil baginya maka semakin baik rangking yang didapatkan, begitu juga sebaliknya, jika hasil baginya semakin besar maka semakin rendah rangkingnya. Rangking inilah yang nantinya akan menentukan kualitas dari sampel dimana rangking 1 berarti sampel memiliki kualitas terbaik dan sampel yang memiliki ranking terbesar memiliki kualitas yang paling rendah.

\section{Hasil dan Pembahasan}

4.1. Hasil penelitian

Penelitian ini memperoleh nilai karakteristik air tanah di sekitar peternakan sapi desa Bercak, Kecamatan Berbah, Kabupaten Sleman, Yogyakarta seperti disajikan pada Tabel 1. Hasil ini kemudian dibandingkan dengan standar baku mutu air berdasarkan Keputusan Menteri Kesehatan RI No. 416/Menkes/Per/IX/1990 [8] tentang syarat-syarat dan pengawasan kualitas air. Karakteristik air tanah ini kemudian dapat dilihat apakah terdapat indikasi pencemaran dan sejauh mana pencemaran ini terjadi akibat adanya peternakan sapi di wilayah tersebut.

Pengujian air tanah ini berdasarkan tiga parameter yaitu parameter fisika, parameter kimia dan parameter biologi. Parameter fisika meliputi daya hantar listrik, tegangan permukaan, indeks bias, jumlah zat padat terlarut, dan kekeruhan, parameter kimia meliputi $\mathrm{pH}$, kesadahan, kandungan nitrat dan nitrit, dan kandungan detergen, serta parameter biologi meliputi jumlah total coliform. 
Tabel 1 Hasil penelitian karakteristik air tanah di sekitar peternakan sapi Desa Bercak, Kecamatan Berbah, Kabupaten Sleman, Yogyakarta.

\begin{tabular}{|c|c|c|c|c|c|c|c|}
\hline \multirow[t]{2}{*}{ Parameter } & \multirow[t]{2}{*}{ Satuan } & \multicolumn{3}{|c|}{$20 \mathrm{~m}$} & \multicolumn{2}{|c|}{$30 \mathrm{~m}$} & $40 \mathrm{~m}$ \\
\hline & & 3 & 4 & 5 & 1 & 6 & 2 \\
\hline \multicolumn{8}{|c|}{ Fisika } \\
\hline Indeks Bias & $\sim$ & $1,3400 \pm$ & $1,3387 \pm$ & $1,3382 \pm$ & $1,3391 \pm$ & $1,3375 \pm$ & $1,3385 \pm$ \\
\hline Tegangan Muka & dyne/cm & $23,9 \pm 0,17$ & $33,4 \pm 0,23$ & $39 \pm 0,2$ & $46,3 \pm 0,03$ & $35 \pm 0,2$ & $44,2 \pm 0,16$ \\
\hline $\begin{array}{l}\text { Daya Hantar Lis- } \\
\text { trik }\end{array}$ & $\mu \mathrm{mho} / \mathrm{cm}$ & $128 \pm 3$ & $91 \pm 2$ & $74 \pm 1$ & $89 \pm 2$ & $100 \pm 2$ & $132 \pm 3$ \\
\hline Viskositas & centipoise & $(85 \pm 7) \cdot 10^{-2}$ & $(85 \pm 7) \cdot 10^{-2}$ & $(89 \pm 8) \cdot 10^{-2}$ & $(85 \pm 7) \cdot 10^{-2}$ & $(86 \pm 7) \cdot 10^{-2}$ & $(86 \pm 7) \cdot 10^{-2}$ \\
\hline Kekeruhan & NTU & 1 & 2 & 1 & 1 & 1 & $<1$ \\
\hline Padatan Terlarut & $\mathrm{mg} / \mathrm{L}$ & 181 & 172 & 172 & 176 & 174 & 166 \\
\hline \multicolumn{8}{|c|}{ Kimia } \\
\hline $\mathrm{pH}$ & $\sim$ & 6,5 & 6,6 & 6,8 & 6,6 & 6,8 & 6,5 \\
\hline Kesadahan & $\mathrm{mg} / \mathrm{L}$ & 117,41 & 113,43 & 117,41 & 117,41 & 103,58 & 111,44 \\
\hline Nitrit & $\mathrm{mg} / \mathrm{L}$ & 0,0041 & $<0,0013$ & 0,238 & 0,0066 & 12,93 & 18,83 \\
\hline Nitrat & $\mathrm{mg} / \mathrm{L}$ & 19,55 & 11,65 & 12,36 & 20,58 & 3 & 4 \\
\hline $\begin{array}{l}\text { Kandungan Deter- } \\
\text { gen }\end{array}$ & $\mathrm{mg} / \mathrm{L}$ & 0,0109 & 0,0076 & 0,0061 & 0,0067 & 0,0022 & 0,0075 \\
\hline \multicolumn{8}{|c|}{ Biologi } \\
\hline Total Coliform & jumlah/100mL & $>1600$ & $>1600$ & $>1600$ & 240 & $>1600$ & $>1600$ \\
\hline
\end{tabular}

\subsection{Hasil Analisa Data}

Hasil pengujian dapat diketahui bahwa air sumur warga sekitar peternakan sapi sebagai sampel merupakan air terpolusi dan dalam kondisi tercemar karena air mengalami penyimpangan dari keadaan normal yang diperbolehkan. Penyimpangan tersebut terjadi pada beberapa parameter yang diuji, antara lain indeks bias, kandungan nitrat, dan total coliform. Kondisi ini membuat kualitas air menurun. Perbandingan kualitas air sumur digunakan untuk menganalisa tingkat kandungan polutan air sumur berdasarkan titik pengambilan sampel. Untuk itu diperlukan metode analisa perankingan yang menunjukkan perbandingan setiap parameter yang duijikan, baik fisika, kimia, maupun biologi serta perbandingan secara umum. Hasil pengujian air sumur dengan menggunakan 6 sampel terlihat pada Tabel 2.

\subsection{Hasil Analisa Data}

Hasil pengujian dapat diketahui bahwa air sumur warga sekitar peternakan sapi sebagai sampel merupakan air terpolusi dan dalam kondisi tercemar karena air mengalami penyimpangan dari keadaan normal yang diperbolehkan. Penyimpangan tersebut terjadi pada beberapa parameter yang diuji, antara lain indeks bias, kandungan nitrat, dan total coliform. Kondisi ini membuat kualitas air menurun. Perbandingan kualitas air sumur digunakan untuk menganalisa tingkat kandungan polutan air sumur berdasarkan titik pengambilan sampel. Untuk itu diperlukan metode analisa perankingan yang menunjukkan perbandingan setiap parameter yang duijikan, baik fisika, kimia, maupun biologi serta perbandingan secara umum. Hasil pengujian air
Tabel 2 Perbandingan kualitas air sumur.

\begin{tabular}{|c|c|c|c|c|c|c|}
\hline \multirow{3}{*}{ Parameter } & \multicolumn{5}{|c|}{ Jenis Sampel } & \multirow{3}{*}{$\frac{40 \mathrm{~m}}{2}$} \\
\hline & \multicolumn{3}{|c|}{$20 \mathrm{~m}$} & \multicolumn{2}{|c|}{$30 \mathrm{~m}$} & \\
\hline & 3 & 4 & 5 & 1 & 6 & \\
\hline \multicolumn{7}{|c|}{ Fisika } \\
\hline Indeks Bias & 6 & 4 & 2 & 5 & 1 & 3 \\
\hline Tegangan Muka & 1 & 2 & 4 & 6 & 3 & 5 \\
\hline Daya Hantar Lis- & & & & & & \\
\hline trik & 5 & 3 & 1 & 2 & 4 & 6 \\
\hline Viskositas & 1 & 1 & 3 & 1 & 2 & 2 \\
\hline Kekeruhan & 2 & 3 & 2 & 2 & 2 & 1 \\
\hline Padatan Terlarut & 5 & 2 & 2 & 4 & 3 & 1 \\
\hline \multicolumn{7}{|c|}{ kimia } \\
\hline $\mathrm{pH}$ & 1 & 2 & 3 & 3 & 3 & 1 \\
\hline Kesadahan & 4 & 3 & 4 & 4 & 1 & 2 \\
\hline Nitrit & 2 & 1 & 6 & 3 & 4 & 5 \\
\hline Nitrat & 5 & 1 & 2 & 6 & 3 & 4 \\
\hline $\begin{array}{l}\text { Kandungan Deter- } \\
\text { gen }\end{array}$ & 6 & 5 & 2 & 3 & 1 & 4 \\
\hline \multicolumn{7}{|c|}{ Biologi } \\
\hline Total Coliform & 2 & 2 & 2 & 1 & 2 & 2 \\
\hline Total & 40 & 29 & 33 & 39 & 29 & 36 \\
\hline Rata-rata & 3,33 & 2,42 & 2,75 & 3,25 & 2,42 & 3,00 \\
\hline Ranking & V & 1 & II & IV & 1 & III \\
\hline
\end{tabular}

sumur dengan menggunakan 6 sampel terlihat pada Tabel 2.

Tabel 2 menyajikan hasil perbandingan kualitas air sumur. Dari hasil tersebut dapat dikatakan bahwa sampel 4 dan 6 memiliki kualitas air yang paling baik dan tingkat pencemarannya paling rendah. Sampel 3 menduduki peringkat yang paling tinggi dibandingkan sampel yang lain. Hal ini menunjukkan sampel 3 memiliki kualitas air yang paling buruk. Dari hasil ini dapat dikatakan bahwa adanya sektor peternakan sapi bukan merupakan polutan yang paling dominan dalam mempengaruhi kualitas air tanah di sekitarnya. Jadi tidak selamanya semakin dekat posisi sampel dengan peternakan sapi yang dianggap sebagai pusat polutan 
kualitas air semakin baik. Hal ini disebabkan oleh beberapa faktor, antara lain: aliran air permukaan dan air tanah, topografi, waktu, dan aktivitas manusia. Aliran air permukaan dan air tanah dipengaruhi oleh topografi/litografi. Daerah resapan air umumnya bertopografi tinggi dengan kemiringan lahan relatif besar karena tinggi muka air tanah relatif dalam akibat drainase ke bawah, sedangkan daerah rendah muka air tanah menjadi dangkal dan pelepasan air tanah menjadi dominan. Makin tua umur batuan dan makin besar tingkat pelapukan batuan mengakibatkan semakin tinggi pelapukan garam yang terlarut dalam tanah. Lamanya air tanah tinggal pada suatu batuan menyebabkan semakin banyak unsur batuan yang terlarut. Aktivitas manusia yang tidak memperhatikan dampak terhadap lingkungan akan mempengaruhi karakteristik dan kualitas air tanah, misalnya pembuangan limbah rumah tangga.

\section{Kesimpulan}

1 Air tanah tidak memenuhi syarat air kualitas air bersih menurut Keputusan Menteri Kesehatan RI No.416/Menkes/Per/IX/1990 tentang syarat-syarat dan Pengawasan Kualitas Air atau dapat dikatakan telah tercemar.

2 Karakteristik air berubah berdasarkan jarak dimana terjadi perbedaan hasil uji baik dari parameter fisika, kimia, maupun biologi. Jarak bukan merupakan satu-satunya faktor yang berpengaruh dalam menentukan kualitas air tanah. Ada beberapa faktor lain yang dapat mempengaruhi kualitas air tanah, antara lain : aliran air permukaan dan air tanah, topografi, waktu, dan aktivitas manusia.

3 Sektor peternakan sapi bukan merupakan faktor dominan yang mempengaruhi kualitas air bersih di desa Bercak, Kec. Berbah, Kab. Sleman, Daerah Istimewa Yogyakarta.

\section{Pustaka}

1. Widyastuti, F.R., et, a.: Upaya pengelolaan lingkungan usaha peternakan sapi di kawasan usahatani terpadu bangka botanical garden pangkalpinang. In: Prosiding Seminar Nasional Pengelolaan Sumber Daya Alam Dan Lingkungan (2013)

2. Fardiaz, S.: Polusi Air Dan Udara. Penerbit Kanisius, Yogyakarta (1992)

3. Sumiarsa, D., et, a.: Perbaikan kualitas limbah cair peternakan sapi perah oleh spirulina sp. Jurnal Akuatika II(2) (2011)

4. Abdulgani, I.K.: Seluk Beluk Mengenai Kotoran Sapi Serta Manfaat Praktisnya

5. Hardjowigeno, S.: Ilmu Tanah. Akademi Presindo, Jakarta (2005)

6. Anonim: Organic Vegetable Cultivation in Malaysia, Malaysia (2005)

7. Siregar: Road Map Teknologi Pemantauan Daerah Aliran Sungai (DAS) Dan Pengolahan Limbah. LIPI, Jakarta (2004)

8. Anonim: Peraturan Menteri Kesehatan No. 416/MENKES/PER/IX/1990 Tentang Syarat-Syarat Dan Pengawasan Kualitas Air, Jakarta (1990) 